\title{
Determinan Kualitas Hasil Audit Aparat Inspektorat dalam Keuangan Daerah Provinsi Nusa Tenggara Barat
}

\author{
Defel Septian' R Ayu Ida Aryani' Muliani
}

Universitas Bumigora

defelubg@gmail.com, ayu.aryani@universitasbumigora.ac.id.mulianipelita@gmail.com

\begin{abstract}
Abstrak
Penelitian ini menggunakan 20 auditor internal Aparatur Inspektorat Nusa Tenggara Barat sebagai sampel, ditentukan berdasarkan metode sampling jenuh atau sensus. Penelitian ini menggunakan analisis regresi linier berganda dengan kualitas hasil audit intern pemerintah daerah sebagai variabel dependen serta independensi, integritas dan kompetensi auditor internal sebagai variabel independen. Hasil penelitian ini menunjukkan bahwa terdapat pengaruh positif dan parsial antara independensi dan integritas auditor terhadap kualitas audit.

Sementara itu, penelitian ini menemukan bahwa kompetensi tidak berpengaruh positif dan signifikan terhadap kualitas hasil audit. Koefisien determinasi menunjukkan bahwa independensi, integritas dan kompetensi secara simultan berpengaruh terhadap variabel dependen (kualitas hasil audit) sebesar 41,5\%, sedangkan sisanya sebesar 58,5\% dipengaruhi oleh faktor lain.
\end{abstract}

Kata Kunci: Independensi, Integritas, Kompetensi, Kualitas Hasil Audit.

\begin{abstract}
This study used 20 internal auditors of West Nusa Tenggara Inspectorate Apparatus as sample, determined based on saturated or census sampling method. This study uses multiple linear regression analysis with the quality of local government internal audit results as the dependent variable as well as the independence, integrity and competence of internal auditors as independent variables. The results of this study indicate that there is positive and partial influence between the independence and auditor integrity to the audit quality.

Meanwhile, the study found that competence has no positive and significant influence on the quality of audit result. The coefficient of determination indicates that the independent, integrity and competence simultaneously affect the dependent variable (the quality of audit result) of $41,5 \%$, while the remaining $58,5 \%$ influenced by other factors.
\end{abstract}

Keywords: Independensi, Integritas, Kompetensi, KualitasHasil Audit. 


\section{Pendahuluan}

Menurut Mardiasmo (2005: 18-20) tiga aspek utama yang mendukungterciptanya pemerintahan yang baik (good governance) yaitu pengawasan, pengendalian, dan pemeriksaan atau audit. Pengawasan merupakan kegiatan yang dilakukan oleh pihak di luar eksekutif, yaitu masyarakat dan Dewan PerwakilanRakyat Daerah (DPRD) untuk mengawasi kinerja pemerintahan. Pengendalian(control) adalah mekanisme yang dilakukan oleh eksekutif untuk menjamin bahwa sistem dan kebijakan manajemen dilaksanakan dengan baik sehingga tujuan organisasi dapat tercapai, sedangkan pemeriksaan (audit) merupakan kegiatan yang dilakukan oleh pihak yang memiliki independensi dan kompetensi profesional untuk memeriksa apakah hasil kinerja pemerintah telah sesuai dengan standar yang ditetapkan.

Inspektorat merupakan lembaga dalam pelaksanaan tugasnya bertanggungjawab langsung kepada Gubernur atau Bupati dan secara teknis administratif mendapat pembinaan dari Sekretaris Daerah, diangkat dan diberhentikan oleh Gubernur atau Bupati sesuai ketentuan/peraturan perundangundangan. Inspektorat Daerah mempunyai tugas dan fungsi, yang secara garis besar meliputi pemeriksaan (audit) dan pembinaan terhadap pelaksanaan tugas pokok dan fungsi SKPD, keuangan, kepegawaian, kekayaan Negara/Daerah, pengusutan laporan/pengaduan masyarakat dan kemudian menindak lanjuti hasilhasil audit (inspektorat.ntbprov.go.id/).

Norma dan ketentuan yang berlaku bagi auditor intern pemerintah terdiri dari Standar Audit Aparat Pengawasan Intern Pemerintahan dan Kode Etik Aparat Pengawasan Intern Pemerintahan. Kode etik bertujuan untuk menjaga perilaku aparat pengawasan intern pemerintahan dalam melaksanakan tugasnya, sedangkan Standar Audit dimaksudkan untuk menjaga mutu kualitas hasil audit yang dilaksanakan aparat pengawasan intern pemerintahan. Dengan adanya aturan tersebut, masyarakat atau pengguna laporan keuangan dapat menilai sejauh mana auditor pemerintahan telah bekerja sesuai dengan standar dan etika yang telah ditetapkan guna menghasilkan kualitas hasil audit yang baik (Ayuningtyas, 2012).

Prinsip-prinsip perilaku yang berlaku bagi auditor dalam kode etik APIP antara lain independensi, integritas, dan kompetensi (PERMENPAN, 2008). Selain itu juga menurut Standar Pemeriksaan Keuangan Negara (SPKN) Tahun 2017, untuk bisa menjalankan tugasnya dengan optimal pemeriksa dituntut harus memahami prinsip-prinsip pelayanan kepentingan publik serta menjunjung tinggi independensi dan integritas. Pemeriksa harus memiliki sikap untuk melayani kepentingan publik, menghargai dan memelihara kepercayaan publik, dan mempertahankan profesionalisme.

Susilawati (2014) meneliti tentang pengaruh independensi terhadap kualitas hasil audit pada Auditor Inspektorat Provinsi Jawa Barat, dari hasil penelitiannya menyatakan bahwa independensi berpangruh positif dan signifikan terhadap kualitas hasil audit. Selanjutnya penelitian yang dilakukan oleh Harahap (2015) menunjukkan bahwa independensi berpengaruh positif terhadap kualitas audit. Namun hasil penelitian yang dilakukan oleh Yarfa'ul (2016) menunjukan hasil yang berbeda, dari hasil penelitiannya menyatakan bahwa independensi auditor tidak berpengaruh terhadap kualitas audit.

Ardi (2014) meneliti tentang pengaruh integritas terhadap kualitas hasil audit Aparat Inspektorat pada Pemerintahan Kabupaten Sukoharjo, dari hasil penelitiannya menyatakan bahwa integritas mempengaruhi kualitas hasil audit. Selanjutnya Pratomo (2015) dari hasil penelitiannya menunjukkan integritas auditor berpengaruh terhadap kualitas audit. Sehingga dari hasil penelitian tersebut auditor bersikap jujur pada peraturan-peraturan dan bekerja sesuai dengan keadaan yang sebenarnya dan tidak menerima segala sesuatu yang bukan haknya. Sedangkan penelitian yang dilakukan oleh Fahdi (2011) dari hasil penelitiannya menyatakan bahwa integritas tidak berpengaruh signifikan terhadap kualitas hasil pemeriksaan (audit).

Ayuningtyas (2012) meneliti tentang pengaruh kompetensi terhadap kualitas hasil audit 
pada Auditor Inspektorat Kota/Kabupaten di Jawa Tengah, dari hasil penelitian menunjukkan bahwa kompetensi berpengaruh signifikan terhadap kualitas hasil audit. Hasil tersebut sejalan yang dilakukan oleh Yusuf (2014) menyatakan bahwa kompetensi berpengaruh terhadap kualitas audit. Sementara Yarfa'ul (2016) dari hasil penelitiannya menunjukkan bahwa kompetensi tidak berpengaruh terhadap kualitas audit.

Penelitian yang sekarang merupakan pengembangan dari penelitian Yarfa'ul (2016) tentang kualitas audit internal Pemerintah Daerah, adapun alasan peneliti melakukan pengembangan penelitian tersebut menurut laporan Badan Pemeriksaan Keuangan RI NTB sejak LKPD T.A 2011 s/d LKPD T.A 2015 Provinsi Nusa Tenggara Barat mendapatkan opini Wajar Tanpa Pengecualian (www.mataram.bpk.go.id/). Prestasi tersebut salah satunya tidak terlepas dari peranan Inspektorat Provinsi Nusa Tenggara Barat selaku auditor internal yang akan tetap mempertahankan opini Wajar Tanpa Pengecualian, guna menghasilkan kualitas hasil audit dan menciptakan pemerintahan yang baik (good governance). Dengan opini Wajar Tanpa Pengecualian yang didapatkan oleh Provinsi Nusa Tenggara Barat selama T.A 2011 s/d T.A 2015, maka peneliti tertarik ingin mengkaji faktor-faktor apa saja yang menentukan kualitas hasil audit yang dihasilkan oleh Provinsi Nusa Tenggara Barat. Serta adanya kesenjangan penelitian terdahulu dalam menciptakan kualitas hasil audit yang baik.

\section{Tinjauan Teoritis}

\section{Teori Atribusi}

Teori atribusi merupakan teori yang menjelaskan tentang perilaku seseorang. Teori atribusi menjelaskan mengenai proses bagaimana kita menentukan penyebab dan motiftentang perilaku seseorang. Teori ini mengacu tentang bagaimana seseorang menjelaskan penyebab perilaku orang lain atau dirinya sendiri yang akan ditentukan apakah dari internal misalnya sifat, karakter, sikap, dll ataupun eksternal misalnya tekanan situasi atau keadaan tertentu yang akan memberikan pengaruh terhadap perilaku individu (Robbins, 2015: 104 ).

Perilaku internal merupakan perilaku individu yang dipercaya berada dalam kendali perilaku pribadi dari individu tersebut (atribut personal seperti kemampuan, usaha dan kelelahan), sedangkan perilaku eksternal merupakan perilaku yang disebabkan dimana situasi memaksa individu untuk melaksanakannya (atribut lingkungan seperti aturan dan cuaca) hal tersebut bersama-sama menentukan perilaku manusia. Teori atribusi menekankan bahwa merasakan secara tidak langsung adalah determinan paling penting untuk perilaku. Atribusi internal maupun eksternal telah dinyatakan dapat mempengaruhi terhadap evaluasi kinerja individu, misalnya dalam menentukan bagaimana cara atasan memperlakukan bawahannya, dan mempengaruhi sikap dan kepuasaan individu terhadap kerja. Orang akan berbeda perilakunya jika mereka lebih merasakan atribut internalnya daripada atribut eksternalnya (Robbins, 2015: 105).

Penelitian ini menggunakan teori atribusi karena peneliti akan melakukan studi empiris untuk mengetahui faktor-faktor auditor yang menghasilkan kualitas hasil audit, khususnya yang diambil dari perlaku auditor itu sendiri. Apakah karakteristik auditor seperti independensi, integritas dan kompetensi berpengaruh positif terhadap kualitas hasil audit. Pada dasarnya karakteristik personal seorang auditor merupakan salah satu penentu terhadap kualitas hasil audit yang akan dilakukan karena merupakan suatu faktor internal yang mendorong seseorang untuk melakukan suatu aktivitas.

\section{Kualitas Hasil Audit}

Auditor pada saat melakukan auditnya, auditor dituntut harus menghasilkan audit yang berkualitas dan sampai saat ini belum ada definisi yang pasti mengenai bagaimana dan apa 
kualitas audit yang baik. Namun Ikatan Akuntan Publik Indonesia (IAI) menyatakan bahwa audit yang dilakukan auditor dikatakan berkualitas, jika memenuhi standar auditing dan standar pengendalian mutu. Kriteria mutu profesional auditor seperti yang diatur oleh standar umum auditing meliputi independensi, integritas dan objektivitas.

Peraturan Menteri Negara Pendayagunaan Aparatur Negara (PERMENPAN) Nomor : Per/05/M.PAN/03/2008 Tentang Standar Audit Aparat Pengawasan Intern Pemerintah (APIP) Seksi 4300 - Kualitas Laporan. Menjelaskan bahwa kualitas laporan yaitu laporan hasil audit kinerja yang harus tepat waktu, lengkap, akurat, obyektif, meyakinkan, serta jelas, dan singkat.

\section{Independensi}

Menurut Mulyadi (2002: 26-27) mendefinisikan indenpendesi sebagai sikap mental yang bebas dari pengaruh, tidak dikendalikan oleh pihak lain, dan tidak tergantung pada orang lain. Independensi juga berarti adanya kejujuran auditor dalam mempertimbangkan fakta dan adanya pertimbangan yang objektif tidak memihak pada diri auditor saat merumuskan dan menyatakan pendapatnya. Auditor dalam setiap menjalankan tugasnya harus independen dari setiap kewajiban atau independen dari pemilikan kepentingan dalam hal yang diauditnya. Di samping itu, Auditor tidak hanya berkawajiban dalam mempertahankan sikap mental independen, tetapi ia harus pula menghindari keadaan- keadaan yang dapat mengakibatkan masyarakat meragukan independensinya.

Auditor dalam menjalankan tugasnya, harus selalu mempertahankan sikap mental independennya pada saat melakukan audit sebagaimana diatur dalam standar profesional akuntan publik yang ditetapkan oleh IAI. Sikap mental independen tersebut harus meliputi independen dalam fakta (in fact) maupun dalam penampilan (in apperance). Independensi dalam fakta (in fact) adalah sikap auditor yang tidak memihak sepanjang pelaksanaan audit. Dalam hal ini, auditor diharuskan untuk objektif dan tidak berprasangka dalam memberikan pendapatnya. Independen dalam penampilan (in apperance) dapat diartikan sebagai hasil interprestasi pihak lain terhadap independensi auditor. Auditor akan dianggap tidak independen apabila memiliki hubungan tertentu dengan klien yang dapat menimbulkanpersepsi dari pihak lain bahwa dirinya tidak independen dalam menjalankan tugasnya (Mulyadi, 2002: 62).

\section{Integritas}

Menurut Mulyadi (2002: 56) integritas adalah suatu elemen karakter yang mendasari timbulnya pengakuan profesional. Integritas merupakan kualitas yang melandasi kepercayaan publik dan merupakan patokan bagi anggota dalam menguji keputusan yang diambilnya. Integritas mengharuskan seorang anggota untuk bersikap jujur dan berterus terang tanpa harus mengorbankan rahasia penerima jasa. Pelayanan dan kepercayaan publik tidak boleh dikalahkan oleh keuntungan pribadi. Integritas dapat menerima kesalahan yang tidak disengaja dan perbedaan pendapat yang jujur, tetapi tidak menerima kecurangan atau peniadaan prinsip.

Peraturan Menteri Negara Pendayagunaan Aparatur Negara (PERMENPAN) tentang Kode Etik Aparat Pengawasan Intern Pemerintah Tahun 2008, menjelaskan bahwa auditor harus memiliki kepribadian integritas yang dilandasi oleh unsur jujur, berani, bijaksana, dan bertanggung jawab untuk membangun kepercayaan guna memberikan dasar bagi pengambilan keputusan yang andal. Integritas merupakan aturan perilaku yang wajib di patuhi oleh auditor APIP pada saat melaksanakan tugasnya. Auditor APIP harus bersikap secara jujur, teliti, bertanggung jawab dan bersungguh-sungguh; menunjukkan kesetiaan dalam segala hal yang berkaitan dengan profesi dan organisasi dalam melaksanakan tugas; mengikuti perkembangan peraturan perundang-undangan dan mengungkapkan segala hal yang ditentukan oleh peraturan perundangundangan dan profesi yang berlaku; menjaga citra dan mendukung visi dan misi organisasi; tidak menjadi bagian kegiatan ilegal, atau mengikatkan diri pada tindakan-tindakan yang dapat mendiskreditkan profesi APIP atau organisasi; menggalang kerja sama yang 
sehat diantara sesama auditor dalam pelaksanaanaudit; saling mengingatkan, membimbing dan mengoreksi perilaku sesama auditor.

\section{Kompetensi}

Mulyadi (2002: 57-58) kompetensi adalah kualitas pribadi yang harus dimiliki oleh seorang auditor yang diperoleh melalui latar belakang pendidikan formal auditing dan akuntansi, pelatihan kerja yang cukup dalam profesi dan akan ditekuninya dan selalu mengikuti pendidikan-pendidikan profesi yang berkelanjutan. Oleh karena itu, dapat dipahami bahwa audit harus dilaksanakan oleh orang yang memiliki keahlian dan pelatihan teknis yang cukup sebagai auditor.

Standar umum audit APIP (Aparat Pengawas Intern Pemerintah) seksi 2220 Kompetensi Teknis, disebutkan bahwa audit harus dilaksanakan oleh orang yang memiliki keahlian dan pelatihan teknis cukup sebagai auditor. Dengan demikian, auditor belum memenuhi persyaratan jika ia tidak memiliki pendidikan dan pengalaman yang memadai dalam bidang audit. Dalam hal auditor melakukan audit terhadap sistem keuangan, catatan akuntansi dan laporan keuangan, maka auditor wajib mempunyai keahlian atau mendapatkan pelatihan di bidang akuntansi sektor publik dan ilmu-ilmu lainnya yang terkait dengan akuntabilitas auditi. Dalam audit pemerintahan, auditor dituntut untuk memiliki dan meningkatkan keampuan atau keahlian bukan hanya dalam metode dan teknik audit, akan tetapi segala hal yang menyangkut pemerintahan seperti organisasi, fungsi, program, dan kegiatan pemerintah.

\section{Pengembangan Hipotesis}

\section{Pengaruh Independensi terhadap Kualitas Hasil Audit}

Berdasarkan penelitian terdahulu mengenai pengaruh independensi terhadap kualitas hasil audit yang dilakukan oleh Irawati (2011), dari hasil penelitiannya menyatakan bahwa independensi berpengaruh terhadap kualitas audit. Selanjutnya penelitian Susilawati (2014), dari hasil penelitiannya juga menyatakan bahwa independensi berpengaruh positif dan signifikan terhadap kualitas hasil audit. Dari ke dua hasil penelitian tersebut menunjukkan bahwa auditor dalam melakukan penyusunan program audit bebas dari campur tanganauditee, intervensi auditee dan usaha-usaha pihak lain untuk menentukan subjek pekerjaan pemeriksaan audit. Maka, jika semakin tinggi independensi seorang auditor maka kualitas hasil audit yang dihasilkannya semakin baik. Berdasarkan uraian tersebut, maka hipotesis yang dirumuskan sebagai berikut :

\section{H1 : Independensi berpengaruh positif terhadap kualitas hasil audit Aparat Inspektorat Dalam Keuangan Daerah Nusa Tenggara Barat \\ Pengaruh Integritas terhadap Kualitas Hasil Audit}

Penelitian yang dilakukan oleh Ardi (2014) yang berjudul "Analisis FaktorFaktor yang Mempengaruhi Kualitas Hasil Audit Aparat Inspektorat Dalam Keuangan Daerah" pada Pemerintahan Kabupaten Sukoharjo, dari hasil penelitiannya menyatakan bahwa ada hubungan antara variabel integritas dengan kualitas hasil audit. Begitu pula pada penelitian yang dilakukan oleh Susilo dan Widyastuti (2014) yang menguji pengaruh integritas terhadap kualitas audit, dari hasil penelitiannya menunjukkan bahwa integritas berpengaruh positif dan signifikan terhadap kualitas audit. Berdasarkan hasil penelitian tersebut, dapat juga membuktikan bahwa integritas berpengaruh terhadap kualitas hasil audit. Sikap integritas mengharuskan auditor untuk bersikap jujur, transparan, berani, bijaksana dan bertanggung jawab dalam melaksanakan audit. Maka, jika seorang auditor memiliki sikap

integritas dalam melakukan audit dapat dikatakan hasil auditnya berkualitas. Berdasarkan uraian tersebut, maka hipotesis yang dirumuskan sebagai berikut : 


\section{H2 : Integritas berpengaruh positif terhadap kualitas hasil audit Aparat Inspektorat Dalam Keuangan Daerah Nusa Tenggara Barat.}

\section{Pengaruh Kompetensi Terhadap Kualitas Hasil Audit}

Penelitian mengenai pengaruh kompetensi terhadap kualitas audit yang dilakukan oleh Sari dan Herry (2011), dari hasil penelitian menunjukkan bahwa kompetensi berpengaruh signifikan terhadap kualitas audit. Penelitian yang dilakukan oleh Harahap (2015) yang mengguji pengaruh kompetensi terhadap kualitas hasil audit pada Auditor BPKP Daerah Istimewa Yogyakarta, menunjukkan bahwa kompetensi berpengaruh positif dan signifikan terhadap kualitas hasil audit. Dari hasil penelitian tersebut menunjukkan bahwa jika semakin tinggi tingkat kompetensi yang dimiliki auditor, maka semakin meningkat atau semakin baik kualitas hasil pemeriksaan yang dilakukannya. Berdasarkan uraian tersebut, maka hipotesis yang dirumuskan sebagai berikut :

\section{H3 : Kompetensi berpengaruh positif terhadap kualitas hasil audit Aparat Inspektorat Dalam Keuangan Daerah Nusa Tenggara Barat.}

\section{Pengaruh Independensi, Integritas dan Kompetensi Terhadap Kualitas Hasil Audit}

Penelitian yang dilakukan ayuningtyas (2012), memberikan hasil bahwa kualitas hasil audit ditentukan oleh lima faktor utama yaitu pengalaman kerja, independensi, obyektifitas, integritas dan kompetensi. Hasil penelitiannya menunjukkan bahwa obyektifitas, integritas dan kompetensi berpengaruh signifikan terhadap kualitas hasil audit. Penelitian selanjutnya yang dilakukan oleh Putra (2015) memberikan hasil bahwa independensi, kompetensi auditor dan pengalaman kerja berpengaruh secara simultan terhadap kualitas hasil audit. Berdasarkan uraian tersebut, maka hipotesis yang dirumuskan sebagai berikut :

\section{H4 : Independensi, Integritas dan Kompetensi berpengaruh secara bersamasama (simultan) terhadap kualitas hasil audit Aparat Inspektorat Dalam Keuangan Daerah Provinsi Nusa Tenggara Barat.}

\section{Metodologi}

\section{Jenis Penelitian}

Jenis penelitian yang digunakan dalam penelitian ini adalah penelitian kausalitas yang bertujuan untuk menjelaskan fenomena dalam bentuk pengaruh antar variabel, yaitu variabel independen terdiri dari : independensi, integritas dan kompetensi. Sedangkan untuk variabel dependen yaitu kualitas hasil audit.

\section{Lokasi Penelitian}

Penelitian ini dilakukan pada Kantor Inspektorat Provinsi Nusa Tenggara Barat yang berlokasi di Jln. Langko No. 27 Selaparang, Kota Mataram.

\section{Populasi dan Sampel}

Populasi dalam penelitian ini adalah seluruh auditor Inspektorat Provinsi Nusa Tenggara Barat yang ikut dalam tugas pemeriksaan yang berjumlah 29 orang, selanjutnya untuk menentukan berapa kira-kira anggota populasi yang akan diambil sebagai sampel, maka apabila subyek kurang dari lima puluh, lebih baik anggota populasi diambil semua sebagai sampel, sehingga penelitian merupakan penelitian populasi (sensus) (Sugiyono, 2001: 61).

\section{Teknik Pengumpulan Data}

Pengumpulan data yang dilakukan pada penelitian ini adalah penelitian lapangan (Field Research), yaitu melakukan penelitian langsung pada objek yang diteliti untuk mengamati lebih dekat hal-hal yang ada hubungannya dengan masalah dalam penelitian ini. Dalam hal ini teknik yang digunakan adalah sebagai berikut: 
a) Wawancara, teknik ini merupakan teknik pengumpulan data yang dilakukan dengan memberi seperangkat pertanyaan kepada responden untuk dijawab.

b) Ceklist, dimana hasil wawancara dinilai dengan menggunakan ceklist, dengan memberikan nilai 1 apa bila dijawab pernah atau dilakukan (Ya) dan 0 apabila dijawab tidak pernah atau tidak dilakukan (Tidak)

Ceklist akan diberikan angka 1 apabila item pernyataan dilakukan (Ya) dan angka 0 apabila item pernyataan tersebut tidak dilakukan (Tidak). Dengan rumus sebagai berikut:

Keterangan :

$$
\mathrm{Y}=\frac{\mathrm{Xn} 1}{\mathrm{XN1}}
$$

Y : Variabel yang ada di dalam penelitian ini

Xn1 : Jumlah item pernyataan pada ceklist untuk Variabel dengan jawaban Ya XN1 : Total seluruh item pernyataan pada ceklist Variabel

\section{Jenis dan Sumber Data}

\section{Jenis Data}

Jenis data yang digunakan pada penelitian ini adalah data kualitatif. Data kualitatif merupakan data non angka yang sifatnya deskriptif dalam bentuk informasi tulisan. Namun data kualitatif tersebut, peneliti mengkuantitatifkan ke dalam bentuk daftar pertanyaan wawancara dan laporan audit responden, dalam hal ini auditor internal Inspektorat Nusa Tenggara Barat untuk memberikan informasi yang dibutuhkan pada penelitian ini.

\section{Sumber Data}

Sumber data yang digunakan pada penelitian adalah data primer. Data primer dalam penelitian ini berupa jawaban para responden atas berbagai pertanyaan dalam ceklist yang telah terstruktur. Daftar ceklist yang telah terstruktur tersebut, bertujuan untuk mengumpulkan informasi dari auditor melalui wawancara langsung kepada auditor Inspektorat Nusa Tenggara Barat. Ceklist yang digunakan.

\section{Uji Hipotesis}

Uji hipotesis dalam penelitian ini adalah dengan menggunakan analisis regresi berganda dan akan menguji pengaruh variabel independen yang terdiri dari independensi, integritas dan kompetensi terhadap variabel dependen yaitu kualitas hasil audit. Alat ujiyang digunakan untuk menguji hubungan variabel tersebut adalah determinasi koefisien (R2), uji t, dan uji F.

\section{Analisis Regresi Berganda}

Analisis regresi berganda digunakan untuk mengetahui ada atau tidaknya pengaruh variabel bebas terhadap variabel terikat. Analisis ini digunakan untuk menjawab bagaimana pengaruh independensi, integritas dan kompetensi terhadap kualitas hasil audit pada kantor Inspektorat Nusa Tenggara Barat. Persamaan yang digunakan dalam analisis regresi linear berganda adalah sebagai berikut:

$$
\mathrm{Y}=\mathrm{a}+\mathrm{b} 1 \mathrm{X} 1+\mathrm{b} 2 \mathrm{X} 2+\mathrm{b} 3 \mathrm{X} 3+\mathrm{e}
$$

\section{Keterangan :}

$$
\begin{aligned}
& \mathrm{Y}=\text { Kualitas hasil Audit } \\
& \mathrm{a}=\text { Nilai intersep (konstan) } \mathrm{b}=\text { Koefisien arah regresi } \mathrm{X} 1=\text { Independensi } \\
& \mathrm{X} 2=\text { Integritas } \mathrm{X} 3=\text { Kompeten }
\end{aligned}
$$




\section{Hasil Dan Pembahasan}

\section{Uji Asumsi Klasik}

\section{a. Uji Normalitas}

\begin{tabular}{|ll|r|}
\hline \multicolumn{2}{|c|}{ One-Sample Kolmogorov-Smirnov Test } \\
\hline N & $\begin{array}{c}\text { Unstandardiz } \\
\text { ed Residual }\end{array}$ \\
Normal Parameters" & Mean & 20 \\
& Std. Deviation & .0000000 \\
Most Extreme Differences & .06866077 \\
& Absolute & .151 \\
& Positive & .101 \\
Kolmogorov-Smirnov Z & Negative & -.151 \\
Asymp. Sig. (2-tailed) & & .675 \\
\hline
\end{tabular}

Test distribution is Normal.

Data Primer Diolah SPSS Versi 16.0, 2017

Nilai Kolmogorov-Smirnov (K-S) adalah 0,675 dengan tingkat probabilitas 0,753, angka probabilitas jauh diatas 0,05 yang artinya data residual terdistribusi normal.

\section{b. Uji Multikolinieritas}

Hasil Uji Multikolinieritas

Coefficients $^{*}$

\begin{tabular}{|c|c|c|c|c|c|c|c|c|}
\hline \multicolumn{9}{|c|}{ Coefficients ${ }^{a}$} \\
\hline \multirow[b]{2}{*}{ Mad } & & \multicolumn{2}{|c|}{ Unstandardized Coefficients } & \multirow{2}{*}{$\begin{array}{c}\text { Standardized } \\
\text { Coefficients } \\
\text { Beta }\end{array}$} & \multirow[b]{2}{*}{$t$} & \multirow[b]{2}{*}{ Siq. } & \multicolumn{2}{|c|}{ Collinearity Statistics } \\
\hline & & B & Std. Error & & & & Tolerance & $\mathrm{VIF}$ \\
\hline \multirow[t]{4}{*}{1} & (Constant) & .286 & .192 & & 1.493 & .155 & & \\
\hline & Independensi & .303 & .115 & .470 & 2.626 & .018 & .962 & 1.040 \\
\hline & Integritas & .476 & .171 & .528 & 2.780 & .013 & .853 & 1.172 \\
\hline & Kompetensi & -.109 & .209 & -.100 & -.520 & 610 & .833 & 1.201 \\
\hline
\end{tabular}

Data Primer Diolah SPSS Versi 16.0, 2017

Hasil besaran korelasi antar variabel independen menunjukkan bahwa tidak ada nilai Tolerance yang memiliki nilai kurang dari 0.10 yang berarti tidak ada korelasi antar variabel independen 95\%. Hasil perhitungan nilai Variance Inflation Factor (VIF) menunjukkan bahwa tidak ada satu variabel independen yang memiliki nilai Variance Inflation Factor (VIF) lebih dari 10. Jadi dapat disimpulkan bahwa tidak ada multikolinieritas antar variabel independen dalam model regresi.

\section{c. Uji Heteroskedatisitas}

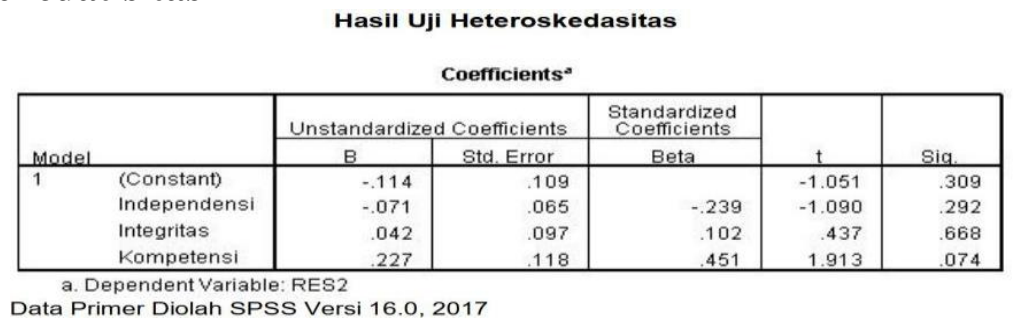

Hasil tingkat signifikansi probabilitas di atas tingkat kepercayaan 5\% sehingga dapat disimpulkan bahwa model regresi tidak mengandung adanya heteroskedastisitas. 


\section{d. Analisis Regresi Berganda}

REGRESI BERGANDA

\begin{tabular}{|c|c|c|c|c|c|c|}
\hline \multicolumn{7}{|c|}{ Coefficients ${ }^{a}$} \\
\hline \multirow[b]{2}{*}{ Model } & & \multicolumn{2}{|c|}{ Unstandardized Coefficients } & \multirow{2}{*}{$\begin{array}{c}\text { Standardized } \\
\text { Coefficients } \\
\text { Beta } \\
\end{array}$} & \multirow[b]{2}{*}{$\mathrm{t}$} & \multirow[b]{2}{*}{ Sig. } \\
\hline & & $\mathrm{B}$ & Std. Error & & & \\
\hline 1 & (Constant) & .286 & .192 & & 1.493 & .155 \\
\hline & Independensi & .303 & .115 & 470 & 2.626 & .018 \\
\hline & Integritas & .476 & .171 & .528 & 2.780 & .013 \\
\hline & Kompetensi & -.109 & .209 & -.100 & -.520 & 610 \\
\hline
\end{tabular}

Persamaan regresi berganda yang diperoleh dari hasil uji statistik pada tabel Regresi Berganda adalah sebagai berikut :

$$
\mathrm{KIA}=0,286+0,470 \mathrm{IA}+0,528 \mathrm{IGA}-, 100 \mathrm{KOA}
$$

\section{UJI SIMULTAN (Uji F)}

\begin{tabular}{|c|c|c|c|c|c|c|}
\hline \multicolumn{7}{|c|}{ ANOVA' } \\
\hline & & $\begin{array}{l}\text { Sum of } \\
\text { Squares }\end{array}$ & df & Mean Square & $\mathrm{F}$ & Sig. \\
\hline \multirow[t]{3}{*}{1} & Regression & .092 & 3 & .031 & 5.484 & $.009=$ \\
\hline & Residual & .090 & 16 & .006 & & \\
\hline & Total & .182 & 19 & & & \\
\hline
\end{tabular}

\section{e. Uji Parsial (Uji Statistik t)}

Berdasarkan tabel Coefficients ${ }^{a}$ dapat diliat variabel Independensi memiliki nilai $\mathrm{t}$ hitung sebesar 2,626 dan nilai t tabel sebesar 1,746 dengan tingkat signifikan 0,018. Secara statistik nilai t hitung yang positif lebih besar dari nilai t tabel $(2,626>1,746)$ dan tingkat signifikansi lebih kecil dari $0,05(0,018<0,05)$ menunjukkan bawah independensi auditor berpengaruh positif dan signifikan terhadap kualitas hasil audit aparat inspektorat dalam keuangan daerah Provinsi Nusa Tenggara Barat, artinya hipotesis satu (H1) diterima.

Berdasarkan tabel Coefficients ${ }^{a}$ dapat diliat variabel Integritas memiliki nilai t hitung sebesar 2,780 dan nilai t tabel sebesar 1,746 dengan tingkat signifikan 0,013. Secara statistik nilai t hitung yang positif lebih besar dari nilai t tabel $(2,780>1,746)$ dan tingkat signifikansi lebih kecil dari $0,05(0,013<0,05)$ menunjukkan bawah integritas auditor berpengaruhpositif dan signifikan terhadap kualitas hasil audit aparat inspektorat dalam keuangan daerah Provinsi Nusa Tenggara Barat, artinya hipotesis dua (H2) diterima.

Berdasarkan tabel Coefficients ${ }^{a}$ dapat diliat variabel Kompetensi memiliki nilai t hitung sebesar -,520 dan nilai t tabel sebesar 1,746 dengan tingkat signifikan 0,610. Secara statistik nilai t hitung yang negatif jauh lebih kecil dari nilai t tabel $(-, 520<1,708)$ dan tingkat signifikansi lebih besar dari $0,05(0,610>0,05)$ menunjukkan bawah kompetensi auditor tidak berpengaruh positif dan signifikan terhadap kualitas hasil audit aparat inspektorat dalam keuangan daerah Provinsi Nusa Tenggara Barat, artinya hipotesis tiga (H3)ditolak.

\section{f. Uji Simultan (Uji F)}

Berdasarkan hasil pengujian terhadap uji simultan ANOVA $^{\mathrm{b}}$ seperti yang ditampilkan pada di atas diperoleh nilai $\mathrm{F}$ hitung sebesar 5,484 dengan probabilitas signifikansi 0,009. Secara statistik nilai $\mathrm{F}$ hitung yang positif lebih besar dari $\mathrm{F}$ tabel $(5,484>3,24)$ dan tingkat signifikansi lebih kecil dari 0,05 $(0,009<0,05)$. Berdasarkan hasil perhitungan tersebut dapat diinterpretasikan bahwa variabel independensi, integritas dan kompetensi berpengaruh positif dan signifikan secara bersama-sama (simultan) terhadap kualitas hasil audit aparat inspektorat dalam keuangan daerah Provinsi Nusa Tenggara Barat, artinya hipotesis empat (H4) diterima. 


\section{Pembahasan}

\section{Pengaruh Independensi terhadap Kualitas Hasil Audit}

Berdasarkan hasil penelitian untuk hipotesis pertama menyatakan bahwa Independensi berpengaruh positif terhadap kualitas hasil audit Aparat Inspektorat dalam Keuangan Daerah Provinsi Nusa Tenggara Barat. Lampiran 2 SPKN disebutkan bahwa "Dalam semua hal yang berkaitan dengan pekerjaan pemeriksaan, organisasi pemeriksa dan pemeriksa, harus bebas dalam sikap mental dan penampilan dari gangguan pribadi, ekstern, dan organisasi yang dapat mempengaruhi independensinya". Sehingga dapat disimpulkan bahwa dengan tingginya tingkat independensi akan berpengaruh secara positif terhadap kualitas hasil audit aparat inspektorat. Berdasarkan hasil pengujian hipotesis, diperoleh hasil penelitian yang menunjukan bahwa independensi berpengaruh secara positif dan signifikan terhadap kualitas hasil audit aparat inspektorat dalam keuangan daerah Provinsi Nusa Tenggara Barat dengan kata lain hipotesis 1 (H1) dalam penelitian ini diterima.

Hasil yang diperoleh dalam penelitian ini untuk independensi auditor Aparat Inspektorat Provinsi Nusa Tenggara Barat sejalan dengan hipotesis awal dan hasil penelitian sebelumnya yang dilakukan oleh Susilawati (2014) dan Harahap (2015) yang menemukan adanya pengaruh positif independensi terhadap kualitas hasil audit. Namun hasil penelitian ini tidak sejalan dengan penelitian sebelumnya yang dilakukan oleh Yarfa'ul (2016) yang menemukan tidak adanya pengaruh independensi terhadap kualitas hasil audit internal.

\section{Pengaruh Integritas terhadap Kualitas Hasil Audit}

Berdasarkan hasil penelitian untuk hipotesis kedua menyatakan bahwa Integritas berpangaruh positif terhadap kualitas hasil aparat inspektorat dalam keuangan daerah Provinsi Nusa Tenggara Barat. Menurut PERMENPAN tentang Kode Etik APIP menjelaskan bahwa auditor harus memiliki kepribadian integritas yang dilandasi oleh unsur jujur, berani, bijaksana, dan bertanggung jawab untuk membangun kepercayaan guna memberikan dasar bagi pengambilan keputusan yang andal. Integritas merupakan aturan perilaku yang wajib di patuhi oleh auditor APIP pada saat melaksanakan tugasnya. Sehingga dapat disimpulkan, jika auditor APIP memiliki kepribadian integritas yang berlandaskan unsur jujur; berani; bijaksana dan bertanggung jawab maka kualitas hasil audit yang dihasilkan berkualitas. Berdasarkan hasil pengujian hipotesis, diperoleh hasil penelitan yang menunjukkan bahwa integritas berpengaruh positif dan signifikan terhadap kualitas hasil audit dengan kata lain hipotesis $2(\mathrm{H} 2)$ dalam penelitian ini diterima.

Hasil yang diperoleh dalam penelitian ini untuk integritas auditor Aparat Inspektorat Provinsi Nusa Tenggara Barat sejalan dengan hipotesis awal dan hasil penelitian sebelumnya yang dilakukan oleh Ardi (2014) dan Pratomo (2015) yang menemukan adanya pengaruh positif integritas terhadap kualitas hasil audit. Namun hasil penelitian ini tidak sejalan dengan penelitian sebelumnya yang dilakukan oleh Fahdi (2011) yang menemukan tidak adanya pengaruh integritas terhadap kualitas hasil audit.

\section{Pengaruh Kompetensi terhadap Kualitas Hasil Audit}

Berdasarkan hasil penelitian untuk hipotesis ketiga menyatakan bahwa kompetensi tidak berpangaruh positif terhadap kualitas hasil aparat inspektorat dalam keuangan daerah Provinsi Nusa Tenggara Barat. Standar umum audit APIP (Aparat Pengawas Intern Pemerintah) seksi 2220 - Kompetensi Teknis, menjelaskan bahwa audit harus dilaksanakan oleh orang yang memiliki keahlian dan pelatihan teknis cukup sebagai auditor. Dengan demikian, auditor belum memenuhi persyaratan jika ia tidak memiliki pendidikan dan pengalaman yang memadai dalam bidang audit. Dalam hal auditor melakukan audit terhadap sistem keuangan, catatan akuntansi dan laporan keuangan, maka auditor wajib mempunyai keahlian atau mendapatkan pelatihan di bidang akuntansi sektor publik dan ilmu-ilmu lainnya 
yang terkait dengan akuntabilitas auditi. Dalam audit pemerintahan, auditor dituntut untuk memiliki dan meningkatkan keampuan atau keahlian bukan hanya dalam metode dan teknik audit, akan tetapi segala hal yang menyangkut pemerintahan seperti organisasi, fungsi, program dan kegiatan pemerintah. Dari penjelasan tersebut dapat disimpulkan bahwa tingkat kompetensi auditor yang baik akan berpengaruh baik pula terhadap kualitas hasil audit yang dihasilkan.

Kompetensi aparat inspektorat Provinsi Nusa Tenggara Barat tidak berpengaruh secara positif terhadap kualitas hasil yang dihasilkan. Hal tersebut disebabkan pertama, 59\% auditor internal inspektorat Provinsi Nusa Tenggara Barat merupakan lulusan nonakuntansi. Jika melihat besarnya lulusan nonakuntansi yang menjadi auditor internal pada kantor inspektorat Provinsi Nusa Tenggara Barat, hal ini dapat menimbulkan pertanyaan dari pengguna laporan hasil pemeriksaan, apakah kualitas hasil audit yang dihasilkan tersebut sudah cukup baik atau tidak, sebab keahlian dalam bidang akuntansi sangat dibutuhkan ketika melakukan pemeriksaan terhadap laporan keuangan pemerintah daerah. Hal ini sesuai dengan pernyataan yang tertera pada SPKN yang menyebutkan bahwa pemeriksa yang melaksanakan pemeriksaan keuangan harus memeiliki keahlian di bidang akuntansi dan auditing, serta memahami prinsip akuntansi yang berlaku umum yang berkaitan dengan entitas yang diperiksa (lampiran 2 SPKN paragraph 11). Kedua, hanya $31 \%$ atau sepertiga dari seratus persen auditor internal aparat inspektorat Provinsi Nusa Tenggara Barat berada pada tingkat pendidikan Strata dua (S2). Namun terlepas dari kedua hal tersebut sebelum responden mendapatkan jabatan fungsional sebagai auditor, auditor harus mencapai angka kredit yang telah ditetapkan dengan cara mengikuti Diklat atau pelatihan sebagai auditor. Sehingga walaupun 59\% latar belakang pendidikan yang dimiliki oleh auditor aparat inspektorat Provinsi Nusa Tenggara Barat adalah nonakuntansi dan $31 \%$ auditor internal aparat inspektorat Provinsi Nusa Tenggara Barat berada pada tinggkat pendidikan Starata dua (S2), auditor tersebut telah mengikuti Diklat atau pelatihan yang cukup sebagai auditor untuk mengaudit laporan keuangan Provinsi Nusa Tenggara Barat.

Hasil yang diperoleh dalam penelitian ini untuk kompetensi auditor Aparat Inspektorat Provinsi Nusa Tenggara Barat tidak tidak sejalan dengan hipotesis awal dan hasil penelitian sebelumnya yang dilakukan oleh Ayuningtyas (2012) dan Harahap (2015) yang menemukan adanya pengaruh positif kompetensi terhadap kualitas hasil audit. Namun hasil penelitian ini sejalan dengan penelitian sebelumnya yang dilakukan oleh Yarfa'ul (2016) yang menemukan tidak adanya pengaruh kompetensi terhadap kualitas hasil audit.

\section{Kesimpulan Dan Saran \\ 1. Kesimpulan}

Hasil empiris penelitian membuktikan bahwa independensi auditor berpengaruh secara positif dan signifikan terhadap kualitas hasil audit aparat inspektorat dalam keuangan daerah Provinsi Nusa Tenggara Barat, hal ini disebabkan auditor pada saat melakukan pemeriksaan bebas dari usaha - usaha (obyek pemeriksaan) untuk menentukan atau menunjuk kegiatan yang diperiksa. Auditor melaporkan kepada pimpinan APIP jika terjadi adanya situasi interprestasi kepentingan, ketidakindependenan atau bias yang dapat mengganggu obyektifitas auditor dan auditor pada saat melaporkan adanya situasi interprestasi tersebut kepada pimpinan APIP, pada saat itu pula auditor digantikan dalam kegiatan auditnya. Selanjutnya auditor mengesampingkan masalah hubungan keluarga, hubungan spesial, dan menghindari hubungan secara personal terhadap auditee pada saat melakukan auditnya guna menjaga independensinya dalam penampilan (independensi in appearance).

Hasil empiris penelitian membuktikan bahwa integritas auditor berpengaruh secara positif dan signifikan terhadap kualitas hasil audit aparat inspektorat dalam keuangan daerah Provinsi Nusa Tenggara Barat, hal ini disebabkan auditor pada saat melaksanakan pemeriksaan, 
selalu taat pada peraturan yang berlaku, tidak diintimidasi dan tidak tunduk karena tekanan yang dilakukan oleh pihak lain. Selanjutnya auditor bertanggung jawab bila hasil pemeriksaannya masih memerlukan perbaikan dan penyempurnaan.

Hasil empiris penelitian membuktikan bahwa kompetensi auditor tidak berpengaruh secara positif dan signifikan terhadap kualitas hasil audit aparat inspektorat dalam keuangan daerah Provinsi Nusa Tenggara Barat, hal ini disebabkan 59\% auditor internal inspektorat Provinsi Nusa Tenggara Barat merupakan lulusan nonakuntansi dan hanya $31 \%$ atau sepertiga dari seratus persen auditor internal aparat inspektorat Provinsi Nusa Tenggara Barat berada pada tingkat pendidikan Strata dua (S2). Namun terlepas dari hal tersebut, sebelum responden mendapatkan jabatan fungsional sebagai auditor, auditor harus mencapai angka kredit yang telah ditetapkan dengan cara mengikuti Diklat atau pelatihan sebagai auditor. Sehingga walaupun 59\% latar belakang pendidikan yang dimiliki oleh auditor aparat inspektorat Provinsi Nusa Tenggara Barat adalah nonakuntansi dan 31\% auditor internal aparat inspektorat Provinsi Nusa Tenggara Barat berada pada tinggkat pendidikan Starata dua (S2), auditior tersebut telah mengikuti Diklat atau pelatihan yang cukup sebagai auditor untuk mengaudit laporan keuangan Provinsi Nusa Tenggara Barat.

Hasil empiris penelitian ini buktikan bahwa independensi, integritas dan kompetensi auditor aparat inspektorat Provinsi Nusa Tenggara Barat berpengaruh secara bersama-sama (simultan) terhadap kualitas hasil audit.

\section{Saran}

Bagi penelitian selanjutnya, untuk menambah responden pada saat penelitian serta memperluas wilayah tempat penelitian yang tadinya penelitian ini hanya bertempat di Kantor Inspektorat Provinsi Nusa Tenggara Barat menjadi seluruh Kantor Inspektorat sepulau lombok dan menambah rentang waktu penelitian yang lebih dari 3 bulan. Serta untuk menambah variabel lain yang tidak termasuk dalam penelitian ini, alangkah baiknya penelitian selanjutnya menambahkan variabel lain tersebut bisa antaranya; obyektifitas, motivasi auditor, pengalaman kerja dan lain-lain.

\section{Daftar Pustaka}

Ardi, Endah Tsalasari Anggun. 2014. Analisis Faktor-Faktor yang Mempengaruhi KualitasHasil Audit Aparat Inspektorat Dalam Keuangan Daerah pada Pemerintah Kabupaten Sukoharjo. Naskah Publikasi. Fakultas Ekonomi dan Bisnis Program Studi Akuntansi Universitas Muhammadiyah Surakarta.

Asosiasi Auditor Intern Pemerintah Indonesia. 2013. Standar Audit Intern Pemerintah Indonesia.

Ayuningtyas, Harvita Yulian. 2012. Pengaruh Pengalaman Kerja, Independensi, Obyektifitas, Integritas dan Kompetensi terhadap Kualitas Hasil Audit pada Auditor Inspektorat Kota/Kabupaten di Jawa Tengah. Skirpsi. Fakultas Ekonomika dan Bisnis Universitas Diponogoro Semarang. Ayura, Dies Pra. 2009. Pengaruh Latar Belakang Pendidikan, Pendidikan Berkelanjutan, Komitmen Organisasi dan Pengalaman Kerja terhadap Kinerja Aparat Pengawas Intern Pemerintah (APIP) pada Inspektorat Provinsi Sumatera Barat. Skripsi. Fakultas Ekonomi Universitas Negeri Padang.

Fahdi, Muhammad. 2011. Pengaruh Pengalaman Kerja, Independensi, Obyektifitas, Integritas, Kompetensi, dan Motivasi Terhadap Kualitas Hasil Pemeriksaan. Jurnal. Fakultas Ekonomi Universitas Riau.

Ghozali, Imam. 2005. Analisis Multivariate dengan Program SPSS. Badan Penerbit Universitas Diponegoro. Semarang. 
Harahap, Lukman. 2015. Pengaruh Kompetensi, Independensi, Obyektifitas dan Sensitivitas Etika Profesi terhadap Kualitas Hasil Audit pada Auditor BPKP Daerah Istimewa Yogyakarta. Skripsi. Program Studi Akuntansi Jurusan Pendidikan Akuntansi Fakultas Ekonomi Universitas Negeri Yogyakarta.

inspektorat.ntbprov.go.id/

Ikatan Akuntansi Indonesia. 2001. Standar Auditing Seksi 210 Tentang Standar Umum Pertama. https://www.dropbox.com/sh/hn5a714lud29ny6/teVSzUQ7UJ. Diakses pada 16 Maret 2017.

Ikatan Akuntansi Indonesia. 2001. Standar Auditing Seksi 322 Tentang Pertimbangan Auditor Atas Fungsi Audit Intern Dalam Audit Laporan Keuangan. https://alengwee.files.wordpress.com/2011/10/sa-seksi-322.pdf. Diakses pada 18 Januari 2017.

Indayani, Putu Ira. 2015. Pengaruh Gender, Tingkat Pendidikan Formal, Pengalaman Kerja Auditor terhadap Kualitas Audit pada Kantor Inspektorat Kota Denpar, Kabupaten Badung dan Kabupaten Buleleng. E-journal S1 AK Volume 3 Nomor 1 Tahun 2015. Jurusan Akuntansi Universitas Pendidikan Ganesha Singaraja.

Irawati, ST Nur. 2011. Pengaruh Kompetensi Dan Independensi Auditor Terhadap Kualitas Audit pada Kantor Akuntan Publik di Makassar. Skripsi. Fakultas Ekonomi Universitas Hasanuddin.

Kovinna, Fransiska. 2013. Pengaruh Independensi, Pengalaman Kerja, kompetensi dan Etika Auditor terhadap Kualitas Audit pada Kantor Akuntan Publik di Kota Palembang. Jurnal. Sekolah Tinggi Ilmu Ekonomi Multi Data Palembang.

Mardiasmo. 2005. Akuntansi Sektor Publik. Penerbit Andi. Yogyakarta.

Mardiasmo. 2006. Pewujudan Transparansi dan Akuntabilitas Publik Melalui Akuntansi Sektor Publik: Suatu Sarana Good Governance. Jurnal Akuntansi Pemerintah Vol. 2, No. 1.

Maryulianti, Hernani. 2015. Determinasi Kualitas Audit dan Pengaruhnya terhadap Fraud Detection pada Laporan Keuangan Kementerian dan Lembaga. Jurnal Bisnis dan Ekonomi. Universitas Sebelas Maret.

Mulyadi. 2002. Auditing, Buku Satu, Edisi Ke Enam. Jakarta : Salemba Empat.

Peraturan Badan Pemeriksaan Keuangan Republik Indonesia No. 01 Tahun 2007. Standar Pemeriksaan Keuangan Negara. Jakarta.

Peraturan Pemerintah Republik Indonesia Nomor 71 Tahun 2010 Tentang Akuntansi Pemerintahan Peraturan Menteri Negara Pendayagunaan Aparatur Negara Nomor PER/04/M.PAN/03/2008. Kode Etik Aparat Pengawasan Intern Pemerintah. Jakarta.

Peraturan Menteri Negara Pendayagunaan Aparatur Negara Nomor PER/05/M.PAN/03/2008. Standar Audit Aparat Pengawasan Intern Pemerintah. Jakarta.

Peraturan Pemerintah Republik Indonesia Nomor 20 Tahun 2015 Tentang Praktik Akuntan Publik.

Pratomo, Riski Setya. 2015. Pengaruh Pengalaman Kerja, Independensi, Obyektifitas, Integritas, Kompetensi dan Akuntanbilitas terhadap Kualitas Hasil Audit pada Kantor Inspektorat Kota/Kabupaten Subosukowonosraten. Naskah Publikasi. Fakultas Ekonomi dan Bisnis Program Studi Akuntansi Universitas Muhammadiyah Surakarta.

Putra, Made Fandy Permana, dkk. 2015. Pengaruh Pengalaman Kerja, Kompetensi Auditor 
Dan Independensi Terhadap Kualitas Hasil Pemeriksaan (Studi Empiris Pada Kantor Inspektorat Kabupaten Buleleng. E-Journal S1 Ak Volume 3 No. 1 Tahun 2015. Jurusan Akuntansi Universitas Pendidikan Ganesha.

Puspitasari, Ratna Fitri. 2015. Pengaruh Pengalaman Kerja, Independensi, Obyektifitas, Integritas, Kompetensi dan Komitmen Organisasi Terhadap Kualitas Audit pada Kantor Akuntan Publik di Wilayah Surakarta daYogyakarta. Naskah Publikasi. Fakultas Ekonomi dan Bisnis Jurusan Akuntansi Universitas Muhammadiyah Surakarta.

Robbins, Stephen P. dan Timothy A. Judge. 2015. Organizational Behaviour, Edisi Ke Enam Belas. Jakarta : Salemba Empat.

Sari, Nungky Nurmalita dan Herry Laksito. 2011. Pengaruh Pengalaman Kerja, Independensi, Obyektivitas, Integritas, Kompetensi dan Etika terhadap Kualitas Audit. Skripsi. Fakultas Ekonomi Universitas Diponegoro.

Setyaningrum, Dyah. 2012. Analisis Faktor-Faktor yang Mempengaruhi Kualitas Audit BPKRI. Jurnal. Universitas Indonesia.

Susilawati, Maya R Atmawinata. 2014. Pengaruh Profesionalisme Dan Independensi Auditor Internal Terhadap Kualitas Audit Pada Inspektorat Profinsi Jawa Barat. Jurnal Etikonomi Vol. 13. STIE STEMBI.

Standar Internasional Praktik Profesional Audit Internal (Standar). https://na.theiia.org/standards-guidance/Public\%20Documents/IPPF-2013 Indonesian.pdf. Diakses pada 25 Desember 2016.

Sugiyono, (2008). Metode Penelitian Kuantitatif, Kualitatif dan R\&D. Bandung : Alfabeta. Susilo, Pria Andono dan Tri Widyastuti. 2014. Integritas, Objektivitas, Profesionalime Auditor dan Kualitas Audit di Kantor Akuntan Publik Jakarta Selatan. Jurnal Riset Akuntansi dan Perpajakan JRAP Vol. 2, No. 1. Fakultas Ekonomi Universitas Pancasila.

Syamsidah. 2016. Pengaruh Latar Belakang Pendidikan, Pengalaman, Pendidikan Berkelanjutan, Ukuran Organisasi dan Kompleksitas Pemerintah terhadap Kualitas Audit BPK RI pada Kementrian Lembaga TA. Tesis. Fakultas Ekonomi dan Bisnis Universitas Lampung.

Yarfa'ul, Ka'asfil. 2016. Faktor-Faktor yang Mempengaruhi Kualitas Audit Internal Pemerintah Daerah Melalui Independensi dan Kompetensi Auditor Internal pada Inspektorat Kota Mataram. Skripsi. Fakultas Ekonomi dan Bisnis Universitas Mataram.

Yusuf, Muhammad. 2014. Pengaruh Kompetensi, Obyektifitas dan Integritas Auditor Terhadap Kualitas Hasil Kerja Auditor pada Auditor BPKP Provinsi Riau. Jurnal. Program Studi Akuntansi Fakultas Ekonomi Universitas Negeri Padang. 